\title{
The Relationship Between Risky Health Behaviors and Satisfaction with Life in University Students
}

\author{
(D) Demet AKTAŞ1, iD Didem POLAT KÜLCÜ22, id Fatma Betül ÖZ³
}

${ }^{1}$ Çankııı Karatekin University Faculty of Health Science, Department of Midwifery, Çankırı, Turkey

${ }^{2}$ Toros University Faculty of Health Sciences, Department of Nursing and Health Services, Mersin, Turkey

${ }^{3}$ Gazi University Faculty of Health Sciences, Ankara, Turkey

\begin{abstract}
Objective: This study was conducted for the purpose of determining relationship between risky health behaviors and satisfaction with life in university students.

Methods: The study was designed as a cross-sectional type. The sampling of the study was createdconsisted of 856 students accepting an education in the different departments of a university in the Mersin in the 2017-2018 spring semester. Three types of data collection tools (Student Introduction Form, Risky Health Behaviors scale (RHBS), and Life Satisfaction scale (LSS) were used in the collection of data in the study. Frequency, mean, standard deviation, t-test, ANOVA and the Pearson correlation analysis were used in the analyses.

Results: The mean risky health behaviors scores (58.68 \pm 7.53) of students in our study were found to be high, and their mean satisfaction with life scores $(16.75 \pm 4.57)$ were found to be moderate. The mean risky health behavior scores are high and mean life satisfaction scores are low for male students, those whose grade point averages are 2.51 and below, those whose parents education level is secondary education and below, those who live away from their family, those whose incomes are less than their expenses, and those whose general health status and interpersonal relationship level is "poor".

Conclusion: Negative, good and moderate correlations were found between life satisfaction and the RHBS psychosocial and nutritional subdimensions, respectively., for the students. It was determined that as the mean total RHBS, psychosocial and nutrition sub-dimension scores of the students increased, their satisfaction with life decreased.
\end{abstract}

Keywords: University student, risky health behavior, life satisfaction

\section{Introduction}

Risky health behaviors are defined as behaviors that are lifethreatening; that result in disease, disability, or death; that prevent one from being a physically, psychosocially, economically, and sexually healthy adult. It is frequently unclear what consequences they will create. In some situations, they include involuntarily making choices (1-4).

Adolescence is a risky process in the emergence of risky health behaviors. The emergence of the needs of students receiving their university education this term, such as the acceleration of physical and psychosocial developments, the development of their autonomy, the increase of their personal responsibilities and their communication within the peer group, and gaining and confirming a place in the peer group, and coming face to face with pressures and different options within the group can trigger the emergence of risky health behaviors $(3,5)$. In these types of situations, the triggering of risky health behaviors frequently originates from being unable to handle the pressure originating from their peer group and difficulties in adapting to a new lifestyle period. Social setting support is very important in adolescents to handle risky health behaviors effectively. It will be easier to

Address for Correspondence: Demet AKTAŞ, Çankırı Karatekin University Faculty of Health Science, 
deal with risky health behaviors in a social environment (e.g. family/friends) that supports the cognitive and psychological development of adolescents, that is a positive role model in behaviors aimed at the development of health, and in which health education is valued $(5,6)$.

Some risky health behaviors gained in adolescence can result in disease, disability, labor loss, economic loss, and death $(3,4)$. Previous studies have determined that the risky health behaviors gained in the adolescence lead to cancer, cardiovascular diseases, cirrhosis, and substance abuse in adulthood $(6,7)$.

Risky health behaviors in university-aged adolescents show variation. These types of behaviors can be sorted as aggressiveness, tendency towards fighting, substance use, burglary, school absence, unprotected sexual relations, unbalanced nutritional habits, and inactivity $(2,8,9)$. Viener et al. (10) reported in their study that $51.2 \%$ of college students smoke cigarettes, drink alcohol, and engage in risky sexual behaviors. Mahallik et al. (11) determined in the study they conducted that the rate of risky sexual behaviors in males in the 20-year-old age group increased significantly (11). It is reported in the literature that the average risky health behavior scores of adolescents are high $(2,9)$. It was determined that the highest average risk scores for the risky social behaviors of adolescents were in the physical activity, nutrition, and hygiene subdimensions and that the lowest average risk score was in the substance use subdimension $(9,12,13)$. The tendency of university-aged adolescents towards risky health behaviors is growing every day (2). It is emphasized that variables such as change in family structure, advancement of technology, societal educational inadequacy, protection-prevention programs not being solution-focused (9), age, gender, substance use, academic success, income level, and dormitory living are influential in the increase of risky behaviors in this group $(2,5,10,12,14)$.

Outlook on life and satisfaction obtained from life are important in the emergence of risky health behaviors in university-aged adolescents. Because, satisfaction with life is a subjective datum that contains an individual's cognitive, psychological, and social evaluations with regard to his or her own living space (15). Therefore, a university-aged adolescent individual positively assessing his/her life expresses his/her satisfaction with his/her life that he/she experiences greater positive affection (16-18). This situation reveals the general idea regarding the satisfaction with life regarding the criteria that individuals specify for a quality, happy, and satisfying life and is a significant finding (16). Satisfaction with life can be affected by some individual traits such as age, gender, income level, education level, religious-cultural beliefs, marital status, and familial and social support (19). Goals and desires regarding the future of students, especially of the college-aged ones, affect their satisfaction with life. However, the decisions for goals and desires, worldviews, passions, and desires to work of the students in their university years which are not fully matured can create stress by negatively affecting their satisfaction with life. Previous studies reported that the academic success, communication with intrafamilial and social environments, and self-respect of university students affected satisfaction with life (16-18). Previous studies have reported that parental support and closeness increase the quality of life in university students and inhibit tendencies towards risky health behaviors $(15,19)$. It was reported that the tendency towards risky health behaviors was high in college students who experienced stress, anxiety, hopelessness, and emotional loneliness and that their satisfaction with life was negatively affected based on this (20). In light of the literature, it is thought that there could be a relationship between satisfaction with life and risky health behaviors that may develop in students in their university years who are in adolescence. Accordingly, this study was conducted for the purpose of determining relationship between risky health behaviors and satisfaction with life in university students.

\section{Methods}

\section{Design}

This study was a cross-sectional type study. This study was conducted with volunteer students who were receiving an education in 15 departments (five departments in the field of health, 10 departments outside of the field of health) that provide undergraduate education in different areas at a university found in the Mersin province in the spring semester of the 2017-2018 academic year.

\section{Sample and Setting}

The population of the study comprises 1.103 students currently receiving an education at a university. The sample size of the study was decided using the "known-population sample size" formula. Disciplines that provide education in the field of health and in a field other than health were divided into categories. The number of students to be taken into each category of sampling was determined in accordance with the weight of the category over the number of students found in the categories. With the simple random sampling method, 509 students receiving an education in the field of health and 347 students receiving an education in a field other than health were included in the study. The study was completed with a total of 856 students.

Students who were 18 years of age and over and who volunteered to participate were included in the study. Students who did not volunteer to participate were not included in the scope of the study.

\section{Data Collection Tools}

Three types of data collection tools were used in the collection of data in the study. Data-collection tools: "Student Introduction Form", "Risky Health Behaviors scale (RHBS)", and "Life Satisfaction scale (LSS)". The researchers gathered the data by distributing the surveys to the students. The researchers prepared the "Student Introduction Form", the first data collection tool, by conducting a literature review, in order to identify the data relating to the socio-demographic characteristics of the students $(1,4,7,10,16)$. This form contained questions that covered the characteristics of the students such as age, gender, class, income level, tendency to get in fights, expectations for the future, and 
loneliness. The second form was the "RHBS". Çimen (21) developed the scale in 2003, and it is used in the determination of risky health behaviors in adolescents. The five-point likerttype scale is composed of 35 items. There are five subdimensions in the scale, including psychosocial, nutrition, physical activity, hygiene and substance use $(20,21)$. The total raw points of the scale are between 34 and 170 . The total raw points obtained from the scale are converted from the absolute value to 100 , and a point scale between 20 and 100 is obtained. Higher total score obtained from the scale and its subdimensions expresses that the risky health behavior score of the individual is high, and lower total score expresses that the risky health behavior score of the individual is low (21). The Cronbach alpha value of the RHBS is 0.86 . The third data collection tool was the "LSS". Diener et al. (22) developed the scale in 1985. The scale aims to identify the satisfaction that individuals in all age groups generally get from life. The original format of the scale is a seven-point likert-type and is composed of five items. The scale is unidimensional. Dağlı and Baysal (23) conducted the validity-reliability study of the scale in our country in 2016 and determined the Cronbach alpha value to be 0.88 . In the Turkish adaptation of the scale, Dağlı and Baysal (23) reduced the number of steps to five by specifying that the answer options in the original form with seven steps were not suitable to Turkish culture, and a five-point likert-type scale was obtained. Low scores obtained from the scale (the lowest is 5) indicate low satisfaction with life, and high scores (the highest is $25)$ indicate high satisfaction with life (23).

\section{Application of the research}

The researchers conducted the study at the start of a class, after receiving permission from the course faculty of the relevant department. The data were collected in approximately 15 minutes.

\section{Ethical Dimension}

Institutional ethics committee approved the study (serial number: 2018/11), and written informed consents were obtained from the students who agreed to participate in the study.

\section{Evaluation of the Data}

The SPSS 22.0 software (SPSS Inc., Chicago, IL, USA) program was used in the analysis of the data. The significance level in the statistical analyses was taken as $\mathrm{p}<0.05$. Frequency, mean, standard deviation, t-test, ANOVA and the Pearson correlation analysis were used in the analyses.

\section{Results}

The mean age of the students was $21.5 \pm 3.03$ years. It was found that the mean of academic grade point average (GPA) of the students was $2.61 \pm 0.61$ and that the mean of LSS was $16.75 \pm 4.57$. It was determined that $69.3 \%$ of the students who participated in the study were in the age group of $\leq 21$ years, $63.9 \%$ were female, and $56.8 \%$ had a GPA of 2.51 and above and that the educational status of the mothers $(62.4 \%)$ and fathers (50.3\%) of more than half of the students was at the secondary school or below. While $74.1 \%$ of the students were living with their families, 59.6\% expressed that they had incomes that were equal to or greater than their expenses. It was reported that $83.7 \%$ of the students had expectations for the future, $70.6 \%$ expressed their general health status as "good", $61.2 \%$ expressed their interpersonal communication level as "good", 69.6\% expressed their quality of life as "high", and $66.1 \%$ expressed their loneliness level as "low".

The average RHBS scores for the university students were found to be $58.68 \pm 7.53$. It was determined that the highest average scores that the students received from the RHBS were in the nutrition $(69.60 \pm 12.13)$, hygiene $(65.88 \pm 9.43)$, physical activity $(52.23 \pm 14.43)$, and psychosocial $(48.95 \pm 10.84)$ subdimensions while the lowest average score was in the substance abuse (28.94 \pm 13.94$)$ subdimension.

Table 1 summarizes the comparisons of RHBS, sub-dimension and LSS, sub-dimension outcomes according to some characteristics of university students. It was reported in our study that the mean scores of female students taken from the RHBS, psychosocial, physical activity, hygiene, and substance use subdimensions were significantly lower than the scores of male students, and it was reported that this difference was statistically significant $(\mathrm{p}<0.001$; Table 1). The mean RHBS scores of the students whose GPAs were 2.50 or below were found to be significantly higher than the average scores of students whose GPAs were 2.51 or above, and it was reported that the difference between the two groups was statistically significant $(\mathrm{p}<0.001)$. It was determined that the mean scores taken from the subdimensions of RHBS, nutrition, hygiene, and substance use of the group of university students whose parents level of education was secondary education or lower, were higher than the group of students whose parents level of education was high school or higher, and that the difference between the two groups was found to be statistically significant $(\mathrm{p}<0.001)$. The mean scores taken from the RHBS, nutrition, hygiene, and substance use subdimensions of the students living with their families were found to be significantly lower than the scores of those living away from their families (e.g. dormitory, friends), and it was reported that this difference was statistically significant $(p<0.001)$. It was determined that mean scores taken from the RHBS, psychosocial, nutrition, hygiene, and substance use subdimensions of the students whose incomes were equal to or greater than their expenses, were lower than those of the students whose incomes were lower than the expenses; and this difference was found to be statistically significant $(\mathrm{p}<0.001$, Table 1). The mean RHBS scores of the college students who expressed that they had no expectations for the future were found in the study to be higher than the average scores of those who expressed that they had expectations for the future, and it was reported that this difference was statistically significant $(p<0.001)$. The mean RHBS scores of the college students who expressed their general health condition as "poor" were found in the study to be considerably higher than the average scores of those who expressed their general health condition as "good", and it was reported that this difference was statistically significant $(p<0.001)$. The mean RHBS scores of the students who expressed their interpersonal communication levels as "good" were found 
in the study to be significantly lower than the average scores of those who expressed their interpersonal communication levels as "poor", and it was reported that this difference was statistically significant $(\mathrm{p}<0.001)$.

It was reported in our study that the mean RHBS and subdimension scores were not affected based on the quality of life variable and that there was no statistically significant difference $(\mathrm{p}>0.05)$.

The mean LSS points of the female students included in the study were higher than the average scores of the male students, and the difference between the two groups was found to be statistically significant $(\mathrm{p}<0.001$, Table 1$)$. It was determined that the mean life satisfaction scores of the students whose GPAs were 2.51 or above were considerably higher than the mean scores of students whose GPAs were 2.50 or below, and it was reported that the difference between the two groups was statistically significant $(p<0.001)$. The mean life satisfaction scores were higher for the students who lived together with their families, whose incomes were equal to or greater than their expenses, and who had expectations for the future than for those who lived away from their families, whose incomes were less than their expenses, and who had no expectations for the future, respectively; and this difference was found to be statistically significant $(p<0.001$, Table 1). The mean life satisfaction scores of the students who expressed their general health status and levels of interpersonal communication as "good" were higher than the students who expressed their general health status and levels of interpersonal communication as "poor", and it was determined that this difference was statistically significant $(\mathrm{p}<0.001)$. The average life satisfaction scores of students with a "high" quality of life were found to be significantly higher than the scores of those with a "low" quality of life, and it was determined that the difference between the groups was statistically significant $(p<0.001)$. The average life satisfaction scores of students with "low" levels of loneliness were significantly higher than the scores of those with "high" levels of loneliness, and it was determined that the difference between the groups was statistically significant $(\mathrm{p}<0.001)$.

Table 1. Comparisons of RHBS-subdimension and LSS- subdimension outcomes according to some characteristics of university students $(n=856)$

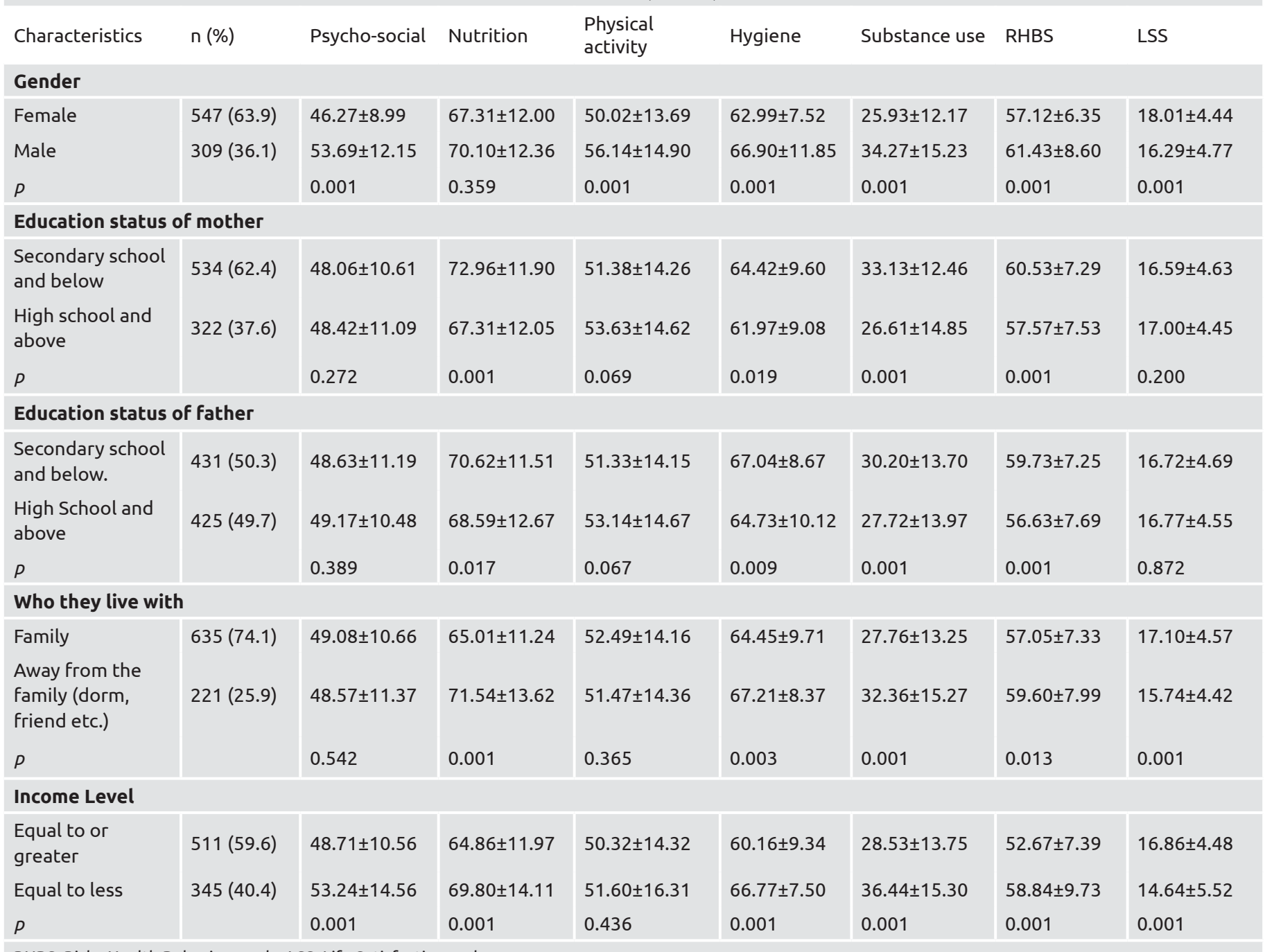




\begin{tabular}{|c|c|}
\hline RHBS & Total LSS \\
\hline \multirow{2}{*}{ Psycho-social } & $r=-0.586$ \\
\hline & $p=0.001$ \\
\hline \multirow{2}{*}{ Nutrition } & $r=-0.485$ \\
\hline & $p=0.001$ \\
\hline \multirow{2}{*}{ Physical activity } & $r=0.191$ \\
\hline & $p=0.794$ \\
\hline \multirow{2}{*}{ Hygiene } & $\Gamma=0.208$ \\
\hline & $p=0.152$ \\
\hline \multirow{2}{*}{ Substance use } & $r=0.102$ \\
\hline & $p=0.631$ \\
\hline \multirow{2}{*}{ Total RHBS } & $r=-0.603$ \\
\hline & $p=0.001$ \\
\hline \multicolumn{2}{|c|}{$\begin{array}{l}\text { r: Correlation coefficient, RHBS: Risky Health Behaviors scale, LSS: Life } \\
\text { Satisfaction scale }\end{array}$} \\
\hline
\end{tabular}

Table 2 provides the correlation between the risky health behaviors and satisfaction with life of the students. Highly negative and moderate correlations were found between the average life satisfaction score and the mean scores in the RHBS, psychosocial and nutritional subdimensions, respectively, for the students. This correlation was statistically significant $(r=-0.603$, $\mathrm{p}=0.001 ; \mathrm{r}=-0.586, \mathrm{p}=0.001 ; \mathrm{r}=-0.485, \mathrm{p}=0.001)$. Based on this, as the average RHBS psychosocial and nutrition subdimension scores of the students increased, their satisfaction with life decreased.

\section{Discussion}

The personal, developmental, and social changes and progressions of students in their college years can lead to stress, and these stress factors that students experience can lead to risky health behaviors that endanger their lives in many areas and can decrease satisfaction with life (2). The average risky health behaviors scores of the students were found to be high and the average life satisfaction scores were found to be moderate in our study. In the studies that Muslu and Aygün (9) and Kalkım and Toraman Uysal (24) conducted, the average risky health behavior scores of university students were found to be high. Özgür et al. (19) found in the study they conducted that the satisfaction with life of students living in dormitories was considerably lower compared with students who live at home. The pressure of societal gender molds the shaping of the identity of students, dilemmas and conflicts experienced within family-peer groups, and individual independence and responsibility in college years can increase the inclination to risky health behaviors $(4,5)$. It was determined in the study that for risky health behaviors, university students received the highest average scores from the nutrition and hygiene subdimensions and the lowest average scores from the substance use subdimension. Previous studies have found that risky behaviors relating to nutrition and hygiene are considerably higher among university students (12,24,25). Change in nutritional behaviors based on changes in lifestyle, inadequacies in social and environmental surroundings (e.g. dormitory environment), body image, and the inability to provide the care necessary for cleanliness and outer appearance increases risk in the nutrition and hygiene subdimensions in university students. The scores of the substance use subdimension were found to be low in our study. However, it is reported in the literature that college students can easily access substances like cigarettes, alcohol, and narcotics and that their substance use subdimension scores were high $(2,4,26)$. Risky health behaviors such as driving while intoxicated, tendency to engage in fights, and smoking cigarettes increase the possibility of disease and injury in adolescent students. This is why, although the average substance use score is low, it should be handled with care.

The average RHBS, psychosocial, physical activity, hygiene, and substance use scores of the male students was found to be higher than the average scores for the female students. As per the societal gender roles in traditionally patriarchal societies, males move more freely and independently. This situation can lead males more easily to attaining harmful substances like cigarettes and alcohol, driving while intoxicated, carrying sharp objectsweapons, and getting injured $(13,14)$. Previous studies have reported that $65 \%$ of males have drank alcohol at least once, $7 \%$ have a substance addiction, and $10-30 \%$ tend to engage in fights $(10,11)$. The tendencies towards risky health behaviors in females are fewer relative to males. Females being raised as individuals responsible for housework, who look after children, who are affectionate, submissive, calm, and dependent on their spouse can partially decrease the tendency towards risky health behaviors (3). Previous studies have reported that males have habits of spending time on the computer and watching television more than females and that this situation increases sedentary living and inclination to obesity $(1,4)$. Adolescent females who are receiving a university education providing more importance to cleanliness, outer appearance, and body image relative to males lowers their risk scores in the physical activity and hygiene subdimensions $(10,25)$. The results of our study are consistent with the literature.

It was determined in our study that the inclination of students whose GPA was 2.50 or below towards risky health behaviors was higher than the average scores of those whose GPA was 2.51 or above. The rate of development of risky health behaviors of students who have low academic success and irregular class attendance and who drop out of school is high $(5,10,14)$. Along with this, antisocial behavior disorders and insufficient social environment support in university students can increase school drop outs, failure in classes, and can lead to an inclination to risky health behaviors $(2,26)$. This is why the low academic success of university students can increase inclination to risky health behaviors.

It was found in our study that the average RHBS, nutrition, hygiene, and substance use scores of students whose parents' level of education was secondary education or below were higher than the students whose parents' education level was high 
school or above. A previous study reported that, as the parents' educational level decreased, awareness and recognition of risky health behaviors diminished, effective communications and expectations between the parents and adolescents could not be ensured, and deficiencies emerged in taking protective measures against risks (6). The results of our study are consistent with the literature. The educational level of parents being high will result in increase in opportunities provided to university students, provision of parental support, and provision of psychosocial support in the necessary conditions by consciously using current opportunities and decrease in the disposition to risky behaviors.

The average scores takenfrom the RHBS, nutrition, hygiene, and substance use subdimensions of the students living with their families were found to be significantly lower than the scores of those living away from their families (e.g. dormitory, friends). Living away from family, having more unfavorable physical opportunities (living in small, crowded environments), encountering the limitations that the operation of shared living spaces brings (inadequacies on the topic of nutrition and hygiene), and experiencing communication problems with the students with whom they live together can trigger predispositions to risky health behaviors in students (3). It was reported that students who received love, interest, and support from their families and who established effective and healthy communication found more effective solutions to the problems $(3,20)$. Especially parental support carries considerable importance in terms of preventing behaviors aimed at substance use and crime in college-aged adolescents. This is why positive support, interest, understanding, and love provided from the family and social environment can inhibit tendency towards risky health behaviors that may develop in students.

In university-aged adolescents with low incomes, unhealthy living conditions relative to those with higher incomes (nutrition, housing, hygiene), deprioritizing health (economic insufficiency and lack of awareness), and being excessively exposed to psychosocial stress factors can increase the predisposition to risky health behaviors $(1,14)$. The average scores taken from the RHBS, psychosocial, nutrition, hygiene, and substance use subdimensions of the students whose incomes were equal to or greater than their expenses were found to be significantly lower than the scores of those whose incomes were less than their expenses. The results of our study are consistent with the literature. On the other hand, it is a notable, significant finding in previous studies that the sedentary living, substance use, and consumption of ready-made foods are much more in students with greater income levels $(4,7,11)$. Income level is a significant variable that affects inclination towards risky health behaviors in university students.

The average risky health behavior scores of the students whose general health condition and interpersonal communication level were "good" and who had expectations for the future were low in our study. Previous studies report that the health status that adolescents perceive, having positive communication with the people they take as role models (e.g. parents, teachers), the inherent support and proximity of their role models, and positive peer relationships far from being pretentious prevent risky health behaviors $(1,3,15)$. Therefore, it is thought that the tendencies towards risky health behaviors may be less in students who positively assess their general perceptions of health, asset goals and expectations on the road to gain knowledge, skill and to have a profession in the university process, and can establish healthy communication in their social environment.

It was determined in our study that satisfaction with life was higher in female students who had high grade point averages, lived with their families, whose incomes were equal to or greater than their expenses, who had expectations for the future, and whose general health status and interpersonal communication level were good. It was reported in previous studies that gender, sociol economic and cultural level, parental behaviors, satisfaction with academic life, getting adequate support from friends and family, having a positive outlook for the future, and subjective status of wellbeing affect satisfaction with life $(15-17,19,20)$. The results of our study are consistent with the literature.

Loneliness finds its foundation from inadequate social relationships and low levels of satisfaction obtained from these relationships (27). Feelings of loneliness carry great importance for students in their college years and can lead to decrease in selfrespect, inadequate social skills, anxiety, substance abuse, obesity, and suicide attempts in university students $(20,23)$. Loneliness and a person's degree of satisfaction with life are directly related to each other. In university students with a high satisfaction with life; loneliness, anxiety, and depression levels were found to be low, and self-respect, level of hope, and academic success were found to be high $(27,28)$. It was determined in our study that the satisfaction with life was low in students who had low level of loneliness. The results of our study are consistent with the literature.

It was also reported in the study that satisfaction with life was high in students with high quality of life. Quality of life includes the relationship with the environment, interactions, and beliefs of people (16). Satisfaction with life is a cognitive assessment that includes quality of life (18). Quality of life and satisfaction with life are in a positive relationship with each other, and, just as in every age group, carry great importance in college. Özgür et al. (19) reported in their study that students with high quality of life had high satisfaction with life. The conclusion of that study shows analogy with the results of our study. Based on the results obtained, it is seen that satisfaction with life increases as quality of life increases.

Highly negative and moderate correlations were found in our study between life satisfaction and the RHBS psychosocial and nutritional subdimensions, respectively, in the students. It was determined that as the risky health behaviors of students increased, their satisfaction with life decreased. Living in a social environment suitable to insight inadequacy in college years (feelings of insignificance and helplessness, depression, aggression, nutrition-housing problems, etc.) can lead students gain risky behaviors $(25,26)$. Therefore, students unable to sufficiently meet their physical, social, and mental needs and 
experiencing helplessness in the solution of their problems, will have increased risky behaviors while significantly decreased satisfaction with life.

\section{Conclusion}

The mean risky health behaviors scores of students in our study were found to be high, and their mean satisfaction with life scores were found to be moderate. Negative good and moderate correlations were found between life satisfaction and the RHBS psychosocial and nutritional subdimensions, respectively, in the students. It was determined that as the mean total RHBS, psychosocial and nutrition sub-dimension scores of the students increased, their satisfaction with life decreased. The mean risky health behavior scores were high and mean life satisfaction scores were low in male students whose GPAs were 2.51 or below, whose parents' education level was secondary education or below, who lived away from their family (e.g. dormitory), whose incomes were less than their expenses, and whose general health status and interpersonal relationship level were "poor". Satisfaction with life was found to be low in students who had "low" quality of life and "high" level of loneliness.

For the prevention of risky health behaviors and increasing the satisfaction with life in students receiving an education at a university; psychosocial educational programs should be organized (sexuality should be considered); effective social support and communication should be strengthened by providing family, academic advising, and student collaboration; and activities should be provided aimed at gaining health life skills (athletic activities, volunteering at aid associations, etc.). The implementation of all these activities aimed at student participation will prevent risky health behaviors and increase satisfaction with life by contributing to the cognitive evaluation of individuals with regard to them being satisfied with their own lives.

\section{Ethic}

Ethics Committee Approval: This study was approved by the Ethics Committee of Çankırı University (serial number: 2018/11).

Informed Consent: Written consent was obtained from the students who agreed to participate in the study.

Peer-review: Externally peer-reviewed.

\section{Authorship Contributions}

Concept: D.A., D.P.K., F.B.Ö., Design: D.A., D.P.K., F.B.Ö., Data Collection or Processing: D.A., D.P.K., F.B.Ö., Analysis or Interpretation: D.A., D.P.K., F.B.Ö., Literature Search: D.A., D.P.K., F.B.Ö., Writing: D.A., D.P.K., F.B.Ö.

Conflict of Interest: The authors declare that they have no conflict of interests.

Financial Disclosure: The authors declared that this study received no financial support.

\section{References}

1. Fırat S, Yoldaşcan E, Çot DA, Dağlığlu N, Gülmen MK. Üniversite öğrencilerinde risk alma davranışları ve etkileyen faktörlerin incelenmesi. Adli Tip Bülteni 2016;21:172-6.

2. Dalkılıç A, Yılmaz H, Unlu A, Evcin U, Prajapati P, Pumariega AJ. Risk factors for suicidal ideation among high school students in İstanbul. Adolescent Psychiatry 2013;3:102-13.

3. Esen Kıran B. Akran baskısı, akademik başarı ve yaş değişkenlerine göre lise öğrencilerinin risk alma davranışının yordanması. Hacettepe Üniversitesi Eğitim Fakültesi Dergisi 2003;24:79-85.

4. Erel Ö, Gölge ZB. Üniversite öğrencilerinde riskli davranışlar ile çocukluk çağı istismar, dürtüsellik ve riskli davranışlar arasındaki ilişki. Anadolu Psikiyatri Dergisi 2015;16:189-97.

5. Oshri A, Tumban JG, Burnette ML. Childhood Maltreatment Histories, Alcohol and Other Drug Use Symptoms and Sexual Risk Behavior in a Treatment Sample of Adolescents. Am J Public Health 2012;102:250-7.

6. Çamur D, Üner S, Çilingiroğlu N, Özcebe H. Bir üniversitenin bazı fakülte ve yüksek okullarında okuyan gençlerde bazı risk alma davranışları. Toplum Hekimliği Bülteni 2007;26:32-8.

7. Kürtüncü M, Uzun M, Ayoğlu NF. Ergen eğitim programının riskli sağlık davranışları ve sağlık algısına etkisi. Journal of Higher Education and Science 2015;5:187-95.

8. Gençtanırım D. Riskli davranışlar ölçeği üniversite formu: geçerlik ve güvenirlik çalışmaları. Journal of Measurement and Evaluation in Education and Psychology 2014;5:24-34.

9. Muslu KG, Aygün Ö. Ergenlerin riskli sağlık davranışlarının ve etkileyen faktörlerin belirlenmesi. DEUHFED 2017;10:242-50.

10. Viener RM, Ozer EM, Denny S, Marmot M, Resnick M, Fatusi A. Adolescence and the social determinants of health. Lancet 2012;379:1641-52.

11. Mahalik JR, Levine CR, McPherran LC, Doyle LA, Markowitz AJ, Jaffee SR. Changes in health risk behaviors for males and females from early adolescence through early adulthood. Health Psychology 2013;32:685-94.

12. Tümer A, Selen Şahin S. Ergenlerin riskli sağlık davranışları. Sağlık ve Toplum 2011;21:32-8.

13. Dabak Ş, Sünter AT, Canbaz S, Pekşen Y. Risky behavior prevalence among Ondokuz Mayıs University students. Türkiye Klinikleri Tıp Bilimleri Dergisi 2010;30:838-46.

14. Birthrong A, Latzman RD. Aspects of impulsivity are differentially associated with risky sexual behaviors. Personality and Individual Differences 2014;57:8-13.

15. Dost MT. Üniversite öğrencilerinin yaşam doyumunun bazı değişkenlere göre incelenmesi. Pamukkale Üniversitesi Eğitim Fakültesi Dergisi 2007;22:132-42.

16. Civitci A. Üniversite öğrencilerinde genel yaşam doyumu ve psikolojik ihtiyaçlar arasındaki ilişkiler. Ç.Ü. Sosyal Bilimler Enstitüsü Dergisi 2012;21:321-36.

17. Yıkılmaz M, Güdül MD. Üniversite öğrencilerinde yaşamda anlam, bilinçli farkındalık, algılanan sosyoekonomik düzey ve yaşam doyumu arasındaki ilişkiler. Ege Journal of Education 2015;16: 297-315. 
18. Çeçen AR. Üniversite ögrencilerinde yaşam doyumunu yordamada bireysel bütünlük (tutarlılık) duygusu, aile bütünlük duygusu ve benlik saygisı. Journal of Theory and Practice in Education 2008;4:19-30.

19. Özgür G, Babacan Gümüş A, Durdu B. Evde ve yurtta kalan üniversite öğrencilerinde yaşam doyumu. Psikiyatri Hemşireliği Dergisi 2010;1:25-32.

20. Fife J, Adegoke A, Mccoy J, Brewer T. Religious commitment, social support and life satisfaction among college students. College Student Journal 2011;45:1-6.

21. Çimen S. 15-18 Yaş grubu gençlerde "riskli sağlık davranışları ölçeği” nin geliştirilmesi. İstanbul: Üniversitesi Sağlık Bilimleri Enstitüsü (Yayınlanmamış Doktora Tezi). 2003.

22. Diener E, Emmons RA, Larsen RJ, Griffin S. The satisfaction with life scale. Journal of Personality Assessment 1985;49:71-5.

23. Dağlı A, Baysal N. Yaşam doyumu ölçeğinin türkçe’ye uyarlanması: geçerlik ve güvenirlik çalışması. Electronic Journal of Social Sciences 2016;15:1250-62.
24. Kalkım A, Toraman Uysal A. Göçmen ve göçmen olmayan ergenlerin riskli sağlık davranışlarının belirlenmesi. TAF Preventive Medicine Bulletin 2014;13;289-94.

25. Peltzer K, Pengpid S. Oral and hand hygiene behaviour and risk factors among in school adolescents in four Southeast Asian countries. Int J Environ Res Public Health 2014;11:2780-92.

26. Jessor R, Turbin MS. Parsing protection and risk for problem behavior versus prosocial behavior among US and Chinese adolescents. Journal of Youth and Adolescence 2014;43:1037-51.

27. Sapmaz F, Doğan T. Mutluluk ve yaşam doyumunun yordayıcısı olarak iyimserlik. Mersin Üniversitesi Eğitim Fakültesi Dergisi 2012;8:63-9.

28. Recepoglu E. Öğretmen adaylarının yaşam doyumları ile öğretmenlik mesleğine ilişkin tutumları arasındaki ilişkinin incelenmesi. Hacettepe Üniversitesi Eğitim Fakültesi Dergisi 2013;1:311-26. 